\title{
Transmission-blocking strategies: the roadmap from laboratory bench to the community
}

\author{
Daniel Gonçalves ${ }^{*}$ and Patrick Hunziker
}

\begin{abstract}
Malaria remains one of the most prevalent tropical and infectious diseases in the world, with an estimated more than 200 million clinical cases every year. In recent years, the mosquito stages of the parasite life cycle have received renewed attention with some progress being made in the development of transmission-blocking strategies. From gametocytes to late ookinetes, some attractive antigenic targets have been found and tested in order to develop a transmission blocking vaccine, and drugs are being currently screened for gametocytocidal activity, and also some new and less conventional approaches are drawing increased attention, such as genetically modified and fungusinfected mosquitoes that become refractory to Plasmodium infection. In this review some of those strategies focusing on the progress made so far will be summarized, but also, the challenges that come from the translation of early promising benchwork resulting in successful applications in the field. To do this, the available literature will be screened and all the pieces of the puzzle must be combined: from molecular biology to epidemiologic and clinical data.
\end{abstract}

Keywords: Transmission blocking strategies, Refractory mosquitoes, Gametocytocidal drugs, Malaria vaccine

\section{Background}

\section{Why block transmission?}

Malaria remains one of the most prevalent tropical and infectious diseases in the world, both, in terms of morbidity and mortality, with around 200 million cases estimated in 2013 alone [1]. Four different species consistently infect humans: Plasmodium falciparum, Plasmodium vivax, Plasmodium malariae, and Plasmodium ovale. From these, $P$. falciparum and $P$. vivax are the most common with the former being by far the most lethal [2-5]. Recently, different accounts of human malaria by another species, Plasmodium knowlesi, which usually infects macaque monkeys, have been reported in Southeast Asia [6].

Since the beginning of the twenty-first Century there has been renewed attention towards the disease, and in 2007 an official research and development agenda for

\footnotetext{
*Correspondence: daniel.goncalves@unibas.ch CLINAM Foundation for Nanomedicine, University of Basel, Basel, Switzerland
}

malaria eradication (malERA) was established [7]. The goal is to completely eliminate and, if possible, eradicate the disease from as many areas as possible and control the others. The main strategies being followed include: the increase of insecticidal nets reach, especially longlasting insecticidal nets (LLINs), within affected communities; use of artemisinin-based combination therapy (ACT) as first-line treatment; and, support the development of a vaccine, with RTS,S/Mosquirix the first being made available and recently approved by the European Medicines Agency (EMA) for children aged 6 weeks to 17 months (exclusively against $P$. falciparum) [8]. Data from 2013 showed that since the beginning of the programme the malaria mortality rate decreased $26 \%$, even with an increase of $43 \%$ in population living in transmission areas [1]. In the 2015 report, WHO estimates that malaria control interventions averted a total of 663 million malaria cases between 2001 and 2015 in sub-Saharan Africa, which $69 \%$ are accounted to the use of insecticide-treated mosquito nets (ITNs), $21 \%$ due to ACT and $10 \%$ due to indoor residual spraying (IRS) [9]. 
While these numbers may be interpreted as progress towards winning this war, recent findings revealed some worrying indicators that Plasmodium is fighting back. Artemisinin and its derivatives are considered the current last line of defence and have been used in combination with other anti-malarials to avoid resistance development, but artemisinin-resistant strains of $P$. falciparum have appeared in Southeast Asia with strong indications of rapid spread [10-16]. Another worrying indicator is Anopheles gambiae (the predominant vector in Africa) resistance to pyrethroids in various sub-Saharan regions [17-20]. The combined proportion of affected population in sub-Saharan Africa with access to IRS and ITNs increased from $2 \%$ in 2000 to $59 \%$ in 2014 [9], and is responsible for reducing child deaths by an average $18 \%$ $[1,21,22]$, but also for spreading pyrethroid resistance. There are four different classes that can be used in IRS, but only pyrethroids are currently recommended for LLINs $[1,21]$.

In recent years, there has been wider interest in mosquito stages as potential targets for new transmissionblocking strategies (TBS) that could help to control, and ultimately, eliminate the disease. New TBS being studied differ mainly from the classical vector control approaches, such as the use of insecticides, because they are designed for mosquito survival, thus avoiding selective pressure towards resistance [23, 24]. Two of the major metrics for malaria transmission intensity are: the basic reproductive number $\left(R_{0}\right)$ representing the number of new cases deriving from one untreated case in an infinite and susceptible human population; and, the entomological inoculation rate (EIR) that measures the rate of Plasmodium-infected mosquito bites per person, per year [25]. Both are of extreme relevance to TBS, not only to provide insights on the impact, but also to set 'critical numbers' as goals for a successful strategy [26-30]. Mathematical modelling based on available field data shows that it should be enough to reduce transmission to $\mathrm{R}_{0}<1$ for a certain period of time to irreversibly compromise the sustainability of the disease [31-34]. In addition, because malaria transmission is a local feature with the source of infection (breeding site) located within a maximum of a $1-\mathrm{km}$ perimeter $[29,35,36]$, TBS are particularly suited to circumscribe small pockets of malaria in isolated communities.

There are three main TBS that are being pursued: gametocytocidal drugs, transmission-blocking vaccines and shifting mosquitoes towards refractory traits. Each of these will be briefly reviewed and a short outlook will present bench progress and challenges, especially largescale implementation and ethical issues, referenced, when possible, with clinical, entomological and field data.

\section{Plasmodium life cycle}

Due to the apicomplexan nature of the Plasmodium life cycle which allows it to survive in different environments, the parasites are well adapted to their obligatory hosts: a vertebrate and the female of the Anopheles genus [37-39].

In humans, the first target of the parasites are the liver cells (hepatocytes), until the point they are released into the blood stream to invade red blood cells in the form of merozoites; it is estimated that each sporozoite that enters the body originates approximately 1000 erythrocyte-infective parasites [40]. Once inside, they reproduce asexually in a (48-h cycle for falciparum) while also forming agglomerates of infected cells to avoid spleen clearance [41]. Eventually, some of the merozoites develop into gametocytes, the sexual form of the parasite, maturing inside the parasitophorous vacuole until released to the peripheral blood, waiting for another mosquito bite to propagate the disease [42]. Parasitaemia in symptomatic infected humans can range from 100 to more than 250,000 parasites per $\mu$ lof blood (hyperparasitaemia) [43, $44]$.

When a female Anopheles mosquito bites an infected vertebrate host, it results in the ingestion of a certain number of gametocytes. Within $15 \mathrm{~min}$, the midgut lumen environment triggers the gametocyte egress and differentiation into micro and macrogametes [45, 46]. The following fusion leads to diploid cells (zygote) that will undergo meiotic division resulting in motile ookinetes $[45,46]$. The main goal of ookinetes is to physically traverse a thick $(1-20 \mu \mathrm{m})$ chitin-based peritrophic membrane (PM) formed upon blood ingestion, and the midgut epithelium [47-49]. The midgut invasion is not pacific and leads to apoptosis of the invaded cells [50,51]. After establishing itself at its basal side, a few parasites (less than ten in average) will develop into the oocyst form, concluding one of the most critical stages in whole life cycle (Fig. 1) [45, 46].

Mitotic divisions start occurring at this stage and ultimately sporozoites are formed. Upon egress from mature oocysts, sporozoites travel via the haemolymph and can be found throughout the mosquito haemocoel until some of them reach the salivary glands [45, 46, 52]. Less than $20 \%$ of the sporozoites entering the haemocoel will establish themselves in the salivary gland with the remaining being eliminated [52].

Transmission of sporozoites occurs when the mosquito ejects saliva into the skin, probing for a blood vessel. Despite some mosquitoes can harbour as many as thousands of sporozoites in their salivary glands, only a small number (10-200) are ejected from the salivary ducts [53, 54]. After their injection into the dermis, they will try to 


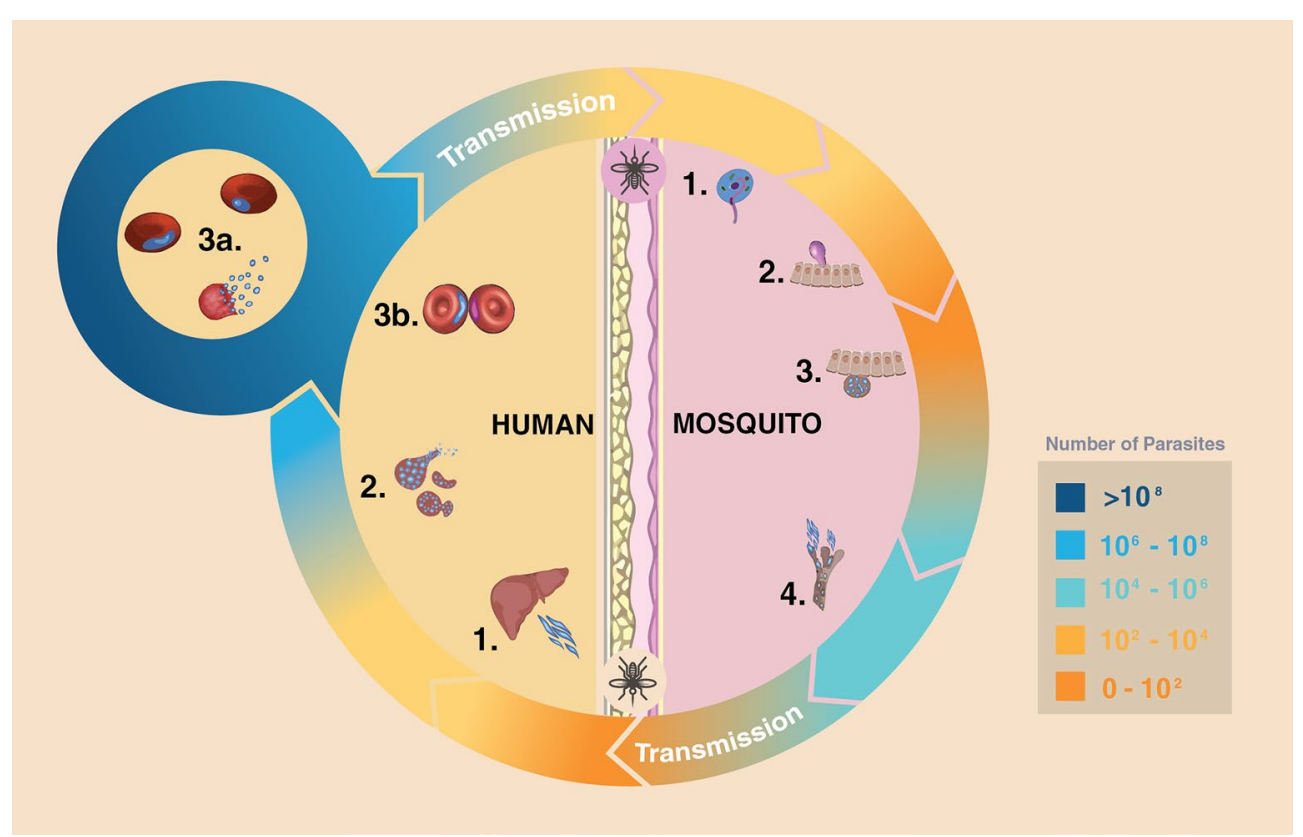

Fig. 1 Representation of the malaria life cycle. Arrows represent the different stages of infection and parasite density, in humans: 1 invasion of hepatocytes, 2 merozoites maturation and release, $3 a$ intra-erythrocytic cycle, 36 gametocytes formation; and, mosquito: 1 gametes egress and fertilization, 2 meiotic division and midgut invasion, 3 oocyst fixation and mitotic division, 4 sporozoites release and salivary glands invasion

find and invade a hepatocyte as soon as possible before detection of the immune system and continue the cycle [55].

In summary, the main differences between the mosquito and humans stages are:

- the mosquito the parasites are exclusively extracellular;

- there are, on average, fewer parasites in the vector comparing to the human host (Fig. 1);

- there are no antibodies produced against Plasmodium in the mosquito despite other mechanisms are available to detect and eliminate the parasites [56, 57];

- morphology and proteome of Plasmodium differ completely from stage to stage, and the only common cells between hosts (excluding the short period of gametocytes in the mosquito) are the sporozoites $[58,59]$;

- mosquito infection is not lethal per se but can be a metabolic and cellular burden, especially during the midgut crossing stage. If this comes with a fitness cost to the mosquitoes in the field is still not clear, with contradictory claims in the literature [60-62].

\section{Gametocyte density and prevalence}

The proportion of merozoites committed to sexual development and the exact mechanism (including sex ratio determination) are not yet fully understood [63-70]. Gametocytogenesis differs between Plasmodium species: while all of them undergo a five-stage maturation process (with some morphological differences), falciparum gametocytes, for example, take the longest (10-12 days as opposed to less than $48 \mathrm{~h}$ for the majority) and are not produced simultaneously with the asexual stages. Mature gametocytes persistence in the peripheral blood is estimated to be lower in P. vivax (approximately 3 days) than in P. falciparum (3.4-6.5 days) [43, 70-72].

High circulating gametocyte numbers do not necessarily result in mosquito infection, and low gametocyte densities do not exclude infectivity; a self-regulated or host-induced response (fever, antibodies, cytokines) still remains unclear $[66,73,74]$. Even so, evidence suggests that transmission success is highly dependent on the proportion of mature gametocytes [75].

Despite all the data available on gametocyte prevalence and density, measuring gametocytaemia levels reliably is still a challenge. The rule of thumb is that the gametocyte count by microscopy techniques usually underestimates the true number by more than $50 \%$ [70, 76]. More sensitive molecular methods such as quantitative nucleic acid sequence-based amplification (QT-NASBA), reverse transcriptase PCR (RT-PCR) and RT loop-mediated isothermal amplification (RT-LAMP) have been developed [77-79]. Despite their usefulness, there is the obvious cost and training barriers for applying any of these 
technologies in the field when the available resources, both human and capital, are already scarce. Thus, a thorough analysis from local authorities and health policy makers to invest in the right resources should be made, being it microscopy, rapid diagnosis tests (RDT) or more advanced molecular biology tools (or a combination of all), resulting in a clear diagnosis strategy defined according to: epidemiological settings of prevalence and density; the health impact of the disease using metrics like the disability-adjusted life year (DALY) in the local population; and economical, not only immediate, such as throughput and cost per unit/case and treatment costs avoided, but also long term, factoring the costs of morbidity and mortality in the socioeconomic advancement of the affected society [80-83].

Various studies have also attempted to estimate the relative contribution to mosquito infection of different patient age groups [68, 84-88]. Despite some evident differences in gametocyte density and prevalence between adults and children, the data are not conclusive and are hard to compare due to lack of consistency in gametocytes estimation methods but also in infection models (skin or membrane feeding assays) $[29,89]$. The non-linear relation, especially at low densities, between human parasitaemia and mosquito infectiousness, and differences in the endemic settings further enhances the challenge in drawing conclusions from these studies. A thorough understanding of the factors determining transmission would not only allow mathematical models to predict the relative contribution of different groups to transmission, but also help to find the most efficient way to implement a TBS and measure its impact.

\section{Transmission-blocking strategies Gametocytocidal drugs}

One of the first approaches to be explored was the gametocytocidal activity of commercially available antimalarial drugs [90]. The rationale was to block transmission by clearing most gametocytes in the human host to render those patients non-infectious to mosquitoes. ACT (artemisinin-piperaquine) combined with a low dose of primaquine (PQ) has been used to help eliminate malaria from 17 Cambodian villages [91], although it is hard to make a clear distinction between the direct effect on gametocytes clearance and the indirect one of ACT reducing the numbers of asexual parasites that could develop into gametocytes [92]. Nevertheless, recognizing the importance of reducing transmission, in 2010 WHO recommended a single dose of PQ of $0.75 \mathrm{mg} / \mathrm{kg}$ as a gametocytocidal agent (not sufficient for hypnozoite clearance in $P$. vivax infections), in combination with ACT making it the first TBS to be endorsed for field application. However, this dose level has restrictions as it should not be given to pregnant women or small children and because there is the risk of haemolysis in people affected with glucose-6-phosphate dehydrogenase (G6PD) deficiency, although it most be said that the deficiency is originated from different variants that translate into different phenotypes (from mild to severe) that must be accounted when determining PQ safety in such patients [93-95]. Finally, in 2012, WHO revised their recommendation to $0.25 \mathrm{mg} / \mathrm{kg}$ in a single dose, but this is still not advised for pregnant women and infants [96].

Responsiveness to drugs is something difficult to compare between Plasmodium species. For $P$. vivax only a few clinical data are available because continuous ex vivo culture methods are not yet ready to screen drugs for gametocytocidal activity [70,97-102]. Even with in vitro culture, where different protocols of sexual stages of $P$. falciparum from gametocytes to ookinetes have been recently made available [103, 104], a relevant limitation in screening anti-malarials and new molecular entities (NMEs) for gametocytocidal activity is the throughput of such models. It certainly opened the door for a wide variety of drugs to be tested using different methods such as ATP bioluminescence, confocal fluorescence and AlarmBlue oxireduction [105-109], but the variability between activity measurements of the same drug, sometimes even with the same method (Table 1), and the lack of a true high-throughput model that is able to screen more than 1000 molecules at a time to effectively search for leads and new scaffolds to design the best drugs for these stages, indicates there is still a lot of progress to be made. There have been some efforts and advances in this direction [110-112] but still far from the standard screening models available for asexual stages [113].

Most of the research is focused on the late gametocyte stage but it is also possible to target the mosquito stages of the parasites (sporontocidal activity), as demonstrated with proguanil, pyrimethamine and most endoperoxides $[70,105]$. The rate and timing at which gametocytes are cleared or neutralized (transmission time-window) is a factor to take into account when considering a transmission blocking drug, for example a single dose of PQ that has very short-live and targets only late gametocytes, may leave a certain number of gametocytes behind that will eventually mature and able to infect mosquitoes [114116]. This would not be the case if used in combination with a sporontocidal drug, but on the other hand the long half-life needed to be effective, is a major challenge to overcome.

A theoretical model recently raised concern by predicting a negative impact on drug resistance for gametocytocidal campaigns, by potentially reducing the transmission of drug-sensitive sexual forms to a greater extent than the drug-resistant ones [117]. Despite the fact that some data 
Table 1 Comparison of in vitro gametocytocidal activities with different methods and anti-malarial drugs

\begin{tabular}{llll}
\hline Drug & $\begin{array}{l}\text { IC50 uM } \\
\text { (stage } \\
\text { IV-V) }\end{array}$ & Method & References \\
\hline Primaquine & $>10$ & ATP bioluminescence & {$[107]$} \\
Mefloquine & 7.2 & HTS confocal fluorescence & {$[109]$} \\
& 100 & HTS confocal fluorescence & {$[109]$} \\
Pyronaridine & 4.7 & ATP bioluminescence & {$[107]$} \\
& 4.260 & HTS confocal fluorescence & {$[109]$} \\
& 3.2 & ATP bioluminescence & {$[107]$} \\
Pentamidine & 0.28 & ATP bioluminescence & {$[106]$} \\
& 0.404 & ATP bioluminescence & {$[106]$} \\
Methylene Blue & 2.85 & HTS confocal fluorescence & {$[109]$} \\
& 0.287 & HTS confocal fluorescence & {$[109]$} \\
& 0.49 & ATP bioluminescence & {$[107]$} \\
Diihydroartemisin & 0.012 & ATP bioluminescence & {$[106]$} \\
& 0.00217 & HTS confocal fluorescence & {$[109]$} \\
Artesunate & 3.56 & ATP bioluminescence & {$[107]$} \\
& 2.53 & HTS confocal fluorescence & {$[109]$} \\
& 2.3 & ATP bioluminescence & {$[106]$} \\
& 10.48 & ATP bioluminescence & {$[107]$} \\
& 0.00042 & ATP bioluminescence & {$[107]$} \\
Epoximicin & 0.0014 & Alamar Blue & {$[108]$} \\
& 0.00066 & HTS confocal fluorescence & {$[109]$} \\
\hline & & &
\end{tabular}

suggest resistance is spreading faster at both ends of the transmission-intensity spectrum [117-120], this possibility has not been conclusively confirmed or refuted by empirical data and, probably, the implications for superinfection (simultaneous infection with multiple genetically distinct parasites) should also be accounted [121].

Another model suggested that increasing ACT coverage would outperform the addition of any specific gametocytocidal drug in reducing transmission [122], but even if true, the spreading of artemisinin resistance and PQ side effects should suffice for investing time and resources in the development of a novel, efficacious, lategametocyte/gamete inhibitor.

\section{Transmission-blocking vaccine}

During 2013, the Malaria Vaccine Initiative (MVI) updated its roadmap and included the development of vaccines interrupting malaria parasite transmission (VIMTs) as one of its strategic goals for the next years $[123,124]$. The vaccine approach aims to achieve transmission reduction through an immunological attack on sexual or mosquito stages of the life cycle. To this end, an immune response in the human host directed to stagespecific targets is required.

Surface proteins of gametocytes and gametes (Pfs 2400, Pfs 230, Pfs 48/45, Pfg 27), zygote and ookinete stages (Ps
25 , Ps 28) have been the principal candidates [70, 125128], but other epitopes from later stages (Ps 21), molecules such as chitinase, which is important for PM and midgut traversal, and alanyl aminopeptidase (AnAPN1), an antigen in the midgut surface, important for ookinete recognition, were identified as potential targets [129, 130]. Since there is a population chokepoint occurring, the appeal, in terms of resistance spread and elimination purposes, of targeting later stages in the mosquito infection is obvious, even if the quantitative translation of reducing parasite numbers in different stages into a successful transmission and propagation of malaria is not well enough understood $[45,46,124,131]$.

To develop a successful vaccine, choosing the best target is just the first step, and the need to find a good production and delivery system, complemented by an appropriate formulation and potential adjuvants, is also important [132, 133]. Apart from killed or attenuated whole pathogens (non-practical for mosquito stages) [134, 135], large-scale production of protein antigens is doable using various recent technologies, either synthetic or recombinant, but correct folding, a prerequisite for achieving highly specific high titres in humans is still a challenge [136-138]. In the case of malaria and transmission-blocking vaccines (TBVs) in particular, several expression systems for recombinant antigens have been used, including Escherichia coli, Lactococcus lactis bacterium models, Baculovirus, yeast (Pichia pastoris, Saccharomyces cerevisae), plant-based systems, and algae [138-144]. Particle-delivery technology, such as viruslike particles (VLP) and nanoparticles, are also being pursued $[143,145]$, and the recently developed DNA vaccine technology has been tried but it is still in a very early stage of development [146-148].

Some candidates using different antigens, production and delivery strategies are currently in preclinical stage and being considered for the first tests in humans [149], and others, such as AnAPN1, are still at earlier stage but nevertheless promising because the antibodies produced appear to inhibit both $P$. falciparum and $P$. vivax [129]. Targeting $P$. vivax is of particular importance since this parasite can stay undetected in the liver in the hypnozoite dormant over 2 years, with PQ being the only medicine to target them at the moment [150]. Two different recombinant strategies (using virus-like and conjugating with Pseudomonas aeruginosa exoprotein A) targeting Pfs 25 antigen are already in phase I of clinical trials $[151,152]$, and are the first official candidates for VIMTs targeting sexual, sporogonic or mosquito-stage antigens (SSM-VIMT) but are still a small fraction of the malaria vaccine pipeline [153].

In addition to the development of a stand-alone SSMVIMT, which would not confer immediate benefit to a 
vaccine recipient, a vaccine targeting both SSM and other stage-malaria antigens is being studied. Examples of such an approach are the fusion of circumsporozoite protein (CSP), Pfs 25 and glutamate-rich protein (GLURP) with Pfs 48/45 [154-156]. Just as targeting antigens from multiple parasite stages may create synergies, the use of a vaccine and drug together could also maximize the impact on transmission for a longer period than a drug alone could. It was also suggested that a SSM-VIMT could be coformulated or co-administrated with another health intervention (as Mosquirix with hepatitis B) that targets the same population to render it directly beneficial to recipients, and overcome some of the ethical issues associated with this kind of intervention $[157,158]$.

\section{Refractory mosquitoes}

Mosquitoes have their own natural mechanisms to fight Plasmodium, with a small percentage of them being refractory to the infection $[38,56,57]$. Researchers have recently started to explore possible ways to exploit this observation in the malaria elimination effort. The idea is to (naturally or artificially) emulate the refractoriness processes in the laboratory and somehow introduce it in the field, in such a way that will eventually shift the mosquito population towards a Plasmodium-resistant vector phenotype. Some of the strategies were borrowed from other vectors and disease control programmes and are already tested in the field on a small scale, and others still are in an early stage of research [158-161]. They fall into three categories: population replacement, artificial gene drive mechanisms and third-party modified organisms as delivery systems. Their common feature is the expression of at least one effector molecule responsible for malaria refractoriness. Since this requisite is not met with population suppression methods, such as the release of insects carrying a dominant lethal genetic systems (RIDL), it is not included in this topic.

An ideal effector molecule will not convey a fitness cost to the insect host and could be used in combination to target different stages of the parasite development. Some candidates already tested include phospholipase A2 (PLA2), shown to inhibit ookinete invasion through an unknown mode of action [162], and salivary gland and midgut peptide 1 (SM1) that is thought to block recognition sites for sporozoites and ookinetes [163].

Population replacement can be achieved by releasing either genetically modified (GM) mosquitoes that express a killing or disabling agent for the malaria parasites [164], or naturally refractory mosquitoes previously selected and reared in the laboratory [162]. For large-scale implementation in the field, mosquito releases would probably need to be preceded with intensive insect elimination campaigns to reduce the native population. Release should be done in a controlled manner backed up with a mathematical model giving insight for the stage, numbers, timing, and location that would maximize the desired genetic shifting of the population [165]. Even if the fitness cost of the desired trait is designed to be minimal, it is very likely that this shifting will not be incremental and self-sustainable, and in order to maintain the modifications, periodic releases of additional insects might be needed [161]. Not only is it difficult and costly to rear such large numbers of mosquitoes to have a meaningful impact on levels of transmission of the disease, there is also the ethical issue behind releasing biting female Anopheles, and before being implemented, a careful sensibilization campaign should be made within affected communities.

As an alternative strategy, gene drive mechanisms have been explored to reduce the number of insects needed (males only) to propagate in a self-sustainable manner without additional releases [161, 164]. Many solutions have been studied, starting from transposable elements that will be integrated randomly across the genome, or 'selfish genes', such as the homing endonuclease genes (HEGs) that are transmitted horizontally within a population by using the host cell DNA repair machinery. The linkage between the drive mechanism and the refractory system deserves special attention and must be engineered in a way that, in case it is broken, there is a safety system to prevent modified insects overtaking the population $[161,164]$. A system consisting of synthetic genetic elements, with mosquito regulatory regions and the HEG I-SceI11-13, has already been demonstrated to substantially increase its transmission to the progeny of An. gambiae [166], and very recently a Cas9-mediated gene drive mechanism was published with very interesting results [167-169].

Finally, life organisms, such as bacteria and fungi [170172], and even viruses [173], have been proposed to be engineered as expressing systems for refractory genes inside the mosquitoes. The diversity of the midgut flora in adult Anopheles is well known and includes Escherichia, Alcaligenes, Pseudomonas, Serratia, and Bacillus, which could be used as paratransgenesis vehicles [174]. One such system has been demonstrated with Escherichia coli expressing a fusion protein of ricin and a singlechain antibody against $\mathrm{Pbs} 2$, inhibiting oocyst formation by $95 \%$ in Anopheles stephensi [175]. The bacterium Wolbachia is a special case that has received much attention lately, as it was observed that infected Anopheles became refractory to malaria to a significant extent without the need of further genetic manipulation, although the detailed molecular mechanisms are still unclear. 
Wolbachia inserts a drive mechanism through cytoplasmic incompatibility, meaning that only when both female and male are infected, the fertilized eggs will hatch normally and the bacteria is transovarially transmitted to the next generation $[160,161,176]$. Another possibility is the use of entomopathogenic fungi: fungal spores may be extremely robust and have the advantage to infect mosquitoes directly via the cuticle. Fungal spores can be integrated into a number of delivery systems, such as indoor spraying or odour-baited traps [159, 177, 178]. One such example is Metarhizium anisopliae, modified to express a fusion protein between SM1 and scorpine (antimicrobial toxin), which was able to reduce $P$. falciparum sporozoite counts by $98 \%$ in An. gambiae [178].

\section{Future perspectives}

A successful wide-scale implementation of TBS for malaria elimination campaigns is still some way in the future. Each strategy has its own unique challenges but there are some common questions and technical limitations that need to be overcome and answered. One of the central questions in TBS research is the quantitative and qualitative relationship between transmission reduction and its impact in the parasite reservoir. Several studies have been made [45, 46, 69, 84-88, 124, 131], but there is still a huge knowledge gap to be filled. Better data are needed for human-to-mosquito (and vice versa) transmission rates, prevalence and density of different mosquito stages, and the relation with geographic and demographics (both human and mosquito). The current limited availability of such data is both a challenge and an avenue for further research to translate TBS from the laboratory bench to the field.

Testing the efficacy of a future transmission-blocking drug or vaccine is a further important requirement. Randomized cluster approaches can be used but the endpoints to assess the clinical relevance of such therapeutics are still not clear $[137,157,179]$. The ideal endpoint should be the reduction of new human infections from the same epidemiological source following the introduction of the intervention, but is very difficult to achieve in the field. An alternative is to measure the reduction in the total number of cases, but then it is impossible to assess the direct contribution of the treatment. Whichever endpoint is chosen, the real world will require a compromise between directly quantifiable impact and epidemiological relevance.

A major concern of TBS is regulatory approval, because a clinical development plan for TBS will certainly be different from those applied to other malaria vaccines and drugs. Encouraged by the US Food and Drug Administration (FDA) which clearly states that there is no legal opposition to licensing, and in view of the momentum of new SSM-TBV projects reaching clinical testing, a work group of international experts was established to assess the requirements of an eventual SSM-VIMT Phase III trial [179]. One of the conclusions highlighted the critical importance of identifying the minimally required efficacy (and coverage) and the need for specific criteria that will inform early clinical decision-making.

Both, compartmental and mechanistic mathematical modelling, are paramount for the progress of any of the strategies discussed above [180-182]. This was also one of the lessons learned during the previous Global Malaria Eradication Programme (GMEP) during the 1950s and 1960s, where dichlorodiphenyltrichloroethane (DDT) was widely used as insecticide until the programme was discontinued due to a combination of resistance, financial constraints and negative environmental impact [183]. Some studies suggest that despite the immediate successes of the programme in certain regions, in others, the gain was lost with resurgence appearing in endemic proportions [184]. Thus, the aim should be a long-term strategy, able to measure and predict its impact locally in a specific set of conditions. This will then allow informed decisions on how, where, and when is the best way to implement a certain TBS, and good models and data are crucial to reach that goal $[185,186]$.

Even if all these challenges are overcome, the costbenefit issue remains. Being a disease that targets mainly populations of underdeveloped countries, cost is always a primary challenge for any type of intervention [187]. Not only the benefit should be proven, but the cost-per-unit should be optimized to make it affordable for mass campaigns. Logistics is another constraint usually associated with malaria since most affected populations live in very remote regions. A positive indicator came from a recently developed vaccine against meningitis (MenAfriVac ${ }^{\circledR}$ ), costing less than US $\$ 0.50$ per dose and able to be removed from constant refrigeration, making it more accessible for handling in remote areas of sub-Saharan Africa [157, 188]. Such features would be highly desirable for a malaria vaccine, but the central question still remains: is it really worth allocating that many resources to develop and implement TBV campaigns in less than optimal efficacy and coverage conditions as seen with Mosquirix [189, 190]? If used in combination with other tools, the answer might be affirmative, the main focus is not to have the maximum clinical effect but to strike a precise and coordinated blow to the parasite reservoir (human and mosquito) to reach a minimum threshold that will compromise its propagation and eventual survival in focal, and eventually global, areas (Figs. 2, 3). 


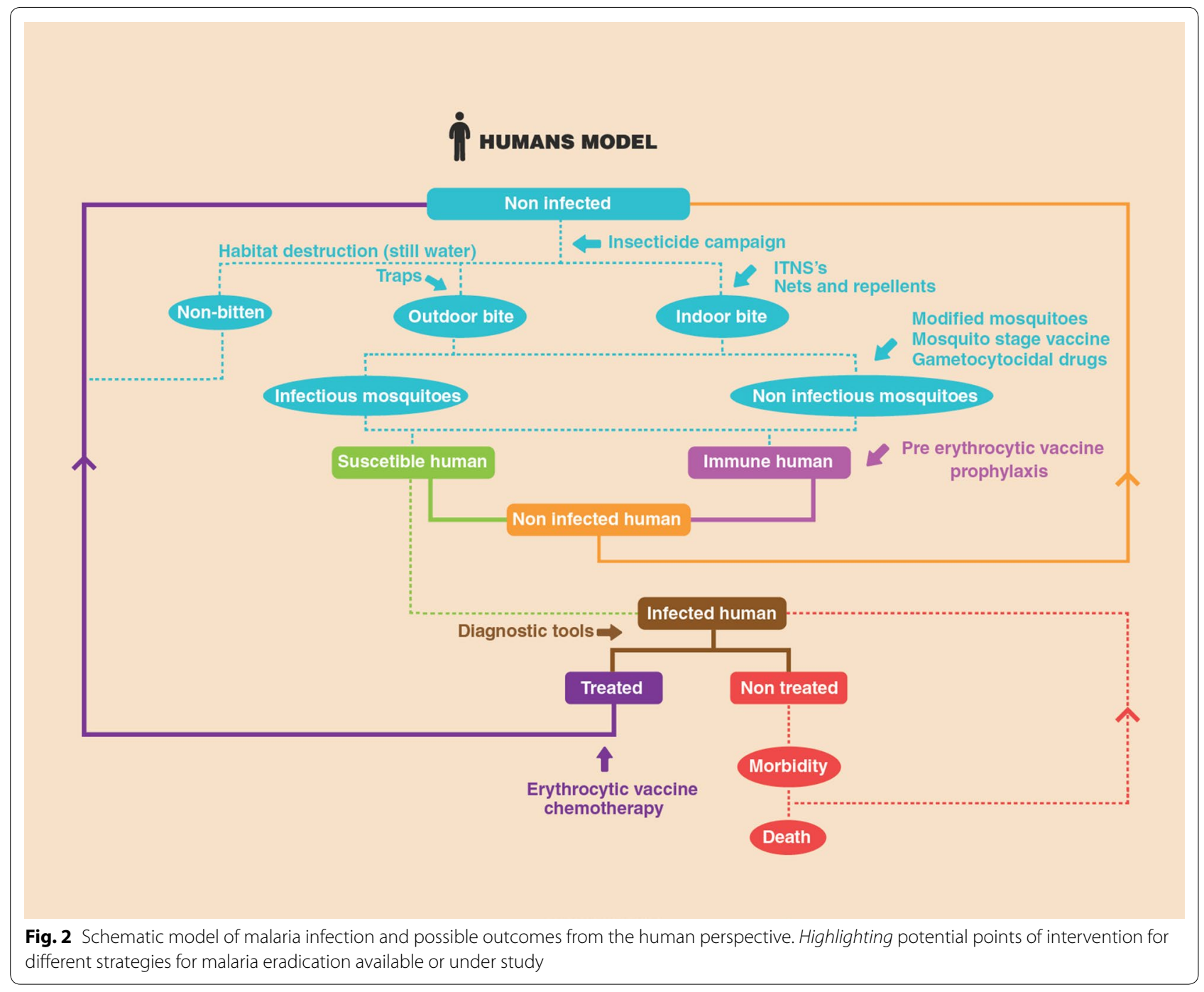

Finally, there is the ethical issue behind using medicines without direct therapeutic benefit to patients, even considering the decreased probability of re-infection. Even if there were no direct benefits, one can argue that individuals taking TB medicines or vaccines is a matter of public health. Education and population sensibilization prior implementation, maybe even more than cost and efficacy, is therefore crucial for any strategy to succeed.

On the other hand, all strategies presented in the 'refractory mosquitoes' topic are far from implementation; despite some promising results, more knowledge such as the epidemiological effects of releasing modified mosquitoes and biopathogens in the field, is needed [164, 191]. Such unconventional approaches might disfavour public awareness and support, but if enough evidence of the positive impact for malaria elimination is gathered and its scalability is proven, then they could become another weapon in the TBS arsenal.

\section{Conclusions}

While it is not expected that TBS will be sufficient to eliminate the disease on their own, their application has the potential to boost other strategies. TBS should be aimed to the lowest endemicity level areas possible $\left(\mathrm{R}_{0}<10\right)$ with frequency and timepoints optimized, taking into account not only the immediate impact in the human reservoir of parasites, but also the long term. In addition, efforts to find the best solution for endpoints and regulatory challenges at clinical trials still need to be made and sensibilization campaigns in affected communities to educate about the beneficial issues of TBS should be a priority.

Any future conventional vaccine for human stages of the disease most likely will be a compromise between efficacy, long-lasting immunity and population coverage. Even if new drugs and insecticides come to market, or resistance against ACT is contained, it is a matter of time 


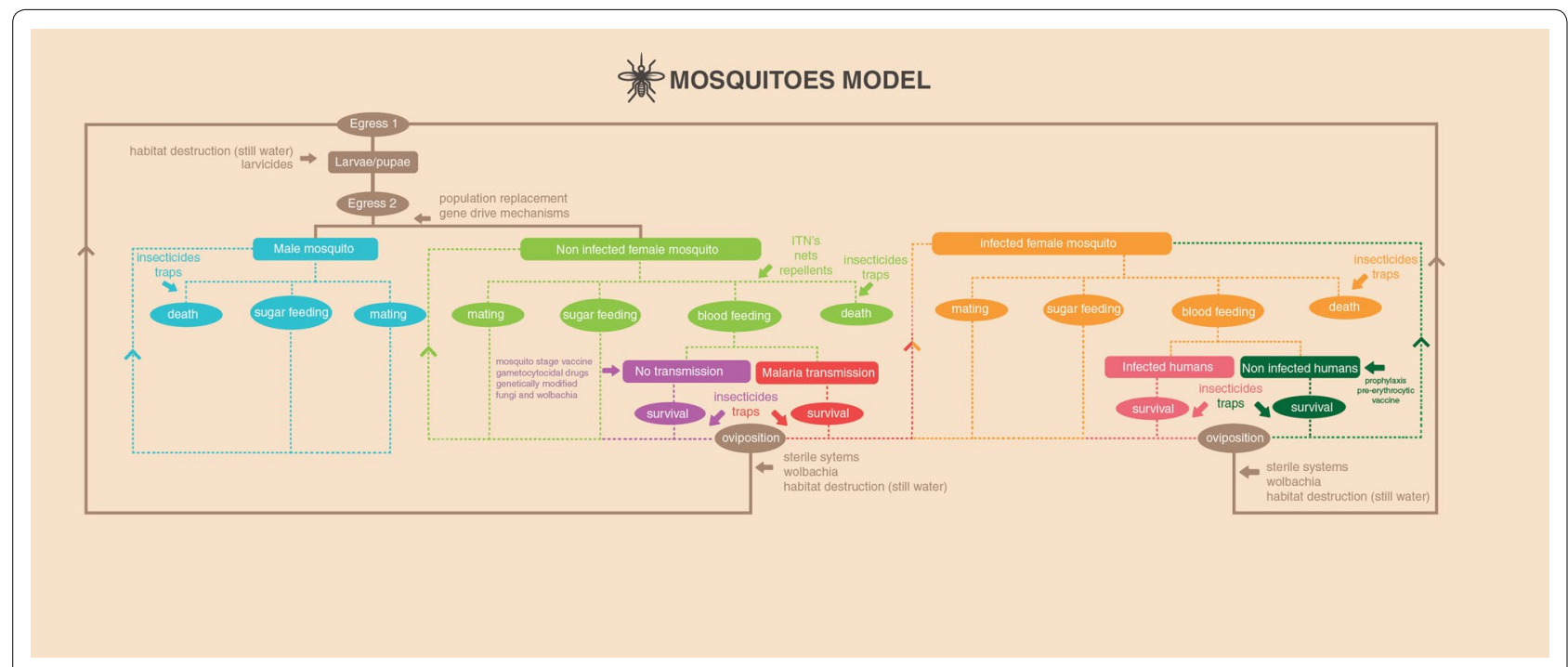

Fig. 3 Schematic model of malaria infection and possible outcomes from the mosquito perspective. Highlighting potential points of intervention for different strategies for malaria eradication available or under study

until they are rendered ineffective. To achieve malaria elimination, all stages should be targeted, preferably at once, and some of the TBS described here, or others to come, most certainly will have a major role to play.

\section{Authors' contributions}

DG drafted the first version and PH reviewed and approved for submission. Both authors read and approved the final manuscript.

\section{Acknowledgements}

The authors want to thank the Swiss Nanoscience Institut for funding and support.

\section{Competing interests}

The authors declare that they have no competing interests.

Received: 5 December 2015 Accepted: 11 February 2016

Published online: 18 February 2016

\section{References}

1. WHO. World malaria report 2014. Geneva: World Health Organization; 2014.

2. Guerra CA, Gikandi PW, Tatem AJ, Noor AM, Smith DL, Hay SI, et al. The limits and intensity of Plasmodium falciparum transmission: implications for malaria control and elimination worldwide. PLoS Med. 2008;5:e38. doi:10.1371/journal.pmed.0050038.

3. Guerra CA, Howes RE, Patil AP, Gething PW, Van Boeckel TP, Temperley WH, et al. The international limits and population at risk of Plasmodium vivax transmission in 2009. PLoS Negl Trop Dis. 2010;4:e774. doi:10.1371/journal.pntd.0000774.

4. Malaria Atlas Project. University of Oxford, UK. 2006. http://www.map. ox.ac.uk/explorer/ Accessed 21 Aug 2015.

5. Murray CJL, Rosenfeld LC, Lim SS, Andrews KG, Foreman KJ, Haring D, et al. Global malaria mortality between 1980 and 2010: a systematic analysis. Lancet. 2012;379:413-31.

6. Kantele A, Jokiranta TS. Review of cases with the emerging fifth human malaria parasite, Plasmodium knowlesi. Clin Infect Dis. 2011;52:1356-62.
7. WHO. MalERA update. World Health Organization, Geneva. http://www. who.int/malaria/elimination/maleraupdate.pdf of subordinate document. Accessed 13 June 2015.

8. EMA. First malaria vaccine receives positive scientific opinion from EMA_London, The European Medicines Agency. http://www.ema. europa.eu/docs/en_GB/document_library/Press_release/2015/07/ WC500190447.pdf of subordinate document. Accessed 3 Feb 2016.

9. WHO. World malaria report 2015. Geneva: World Health Organization; 2015.

10. Dondorp AM, Nosten F, Yi P, Das D, Phyo AP, Tarning J, et al. Artemisinin resistance in Plasmodium falciparum malaria. N Engl J Med. 2009:361:455-67.

11. Amaratunga C, Sreng S, Suon S, Phelps ES, Stepniewska K, Lim P, et al. Artemisinin-resistant Plasmodium falciparum in Pursat province, western Cambodia: a parasite clearance rate study. Lancet Infect Dis. 2012;12:851-8.

12. Kyaw MP, Nyunt MH, Chit K, Aye MM, Aye KH, Lindegardh N, et al. Reduced susceptibility of Plasmodium falciparum to artesunate in southern Myanmar. PLoS ONE. 2013;8:e57689. doi:10.1371/journal. pone.0057689.

13. O'Brien C, Henrich PP, Passi N, Fidock DA. Recent clinical and molecular insights into emerging artemisinin resistance in Plasmodium falciparum. Curr Opin Infect Dis. 2011;24:570-7.

14. Phyo AP, Nkhoma S, Stepniewska K, Ashley EA, Nair S, McGready R, et al. Emergence of artemisinin-resistant malaria on the western border of Thailand: a longitudinal study. Lancet. 2012;379:1960-6.

15. Hien TT, Thuy-Nhien NT, Phu NH, Boni MF, Thanh NV, Nha-Ca NT, et al. In vivo susceptibility of Plasmodium falciparum to artesunate in Binh Phuoc province, Vietnam. Malar J. 2012;11:355.

16. Ashley EA, Dhorda M, Fairhurst RM, Amaratunga C, Lim P, Suon S, et al. Spread of artemisinin resistance in Plasmodium falciparum malaria. N Engl J Med. 2014;371:411-23.

17. Ranson H, N'Guessan R, Lines J, Moiroux N, Nkuni Z, Corbel V. Pyrethroid resistance in African anopheline mosquitoes: What are the implications for malaria control? Trends Parasitol. 2011;27:91-8.

18. Protopopoff N, Matowo J, Malima R, Kavishe R, Kaaya R, Wright A, et al. High level of resistance in the mosquito Anopheles gambiae to pyrethroid insecticides and reduced susceptibility to bendiocarb in north-western Tanzania. Malar J. 2013;12:149.

19. Toé KH, Jones CM, N'Fale S, Ismail HM, Dabiré RK, Ranson H. Increased pyrethroid resistance in malaria vectors and decreased bed net effectiveness, Burkina Faso. Emerg Infect Dis. 2014;20:1691-6. 
20. Trape JF, Tall A, Diagne N, Ndiath O, Ly AB, Faye J, et al. Malaria morbidity and pyrethroid resistance after the introduction of insecticide-treated bednets and artemisinin-based combination therapies: a longitudinal study. Lancet Infect Dis. 2011;11:925-32.

21. Malaria Consortium. Malaria prevention: insecticides. http://www. malariaconsortium.org/userfiles/file/Malaria\%20resources/Insecticides\%202.pdf of subordinate document. Accessed 6 Sept 2015.

22. Eisele TP, Larsen D, Steketee RW. Protective efficacy of interventions for preventing malaria mortality in children in Plasmodium falciparum endemic areas. Int J Epidemiol. 2010;39:88-101.

23. Ramirez JL, Garver LS, Dimopoulos G. Challenges and approaches for mosquito targeted malaria control. Curr Mol Med. 2009;9:116-30.

24. Nwane P, Etang J, Chouaïbou M, Toto JC, Koffi A, Mimpfoundi R, et al. Multiple insecticide resistance mechanisms in Anopheles gambiae s.l. populations from Cameroon, Central Africa. Parasit Vectors. 2013;6:41.

25. Smith DL, McKenzie FE. Statics and dynamics of malaria infection in Anopheles mosquitoes. Malar J. 2004;3:13.

26. Smith DL, McKenzie FE, Snow RW, Hay SI. Revisiting the basic reproductive number for malaria and its implications for malaria control. PLoS Biol. 2007;5:e42. doi:10.1371/journal.pbio.0050042.

27. Kelly-Hope LA, McKenzie FE. The multiplicity of malaria transmission: a review of entomological inoculation rate measurements and methods across sub-Saharan Africa. Malar J. 2009;8:19.

28. Smith DL, Dushoff J, Snow RW, Hay SI. The entomological inoculation rate and Plasmodium falciparum infection in African children. Nature. 2005:438:492-5.

29. Bøgh C, Lindsay SW, Clarke SE, Dean A, Jawara M, Pinder M, Thomas $C J$. High spatial resolution mapping of malaria transmission risk in the Gambia, west Africa, using LANDSAT TM satellite imagery. Am J Trop Med Hyg. 2007;76:875-81

30. Smith T, Schapira A. Reproduction numbers in malaria and their implications. Trends Parasitol. 2012;28:3-8.

31. Blagborough AM, Churcher TS, Upton LM, Ghani AC, Gething PW, Sinden RE. Transmission-blocking interventions eliminate malaria from laboratory populations. Nat Commun. 2013;4:1812.

32. Macdonald G, Goeckel GW. The malaria parasite rate and interruption of transmission. Bull World Health Organ. 1964;31:365-77.

33. Johnston GL, Smith DL, Fidock DA. Malaria's missing number: calculating the human component of RO by a within-host mechanistic model of Plasmodium falciparum infection and transmission. PLoS Comput Biol. 2013;9:e1003025. doi:10.1371/journal.pcbi.1003025.

34. Tusting LS, Bousema T, Smith DL, Drakeley C. Measuring changes in Plasmodium falciparum transmission: precision, accuracy and costs of metrics. Adv Parasitol. 2014;84:151-208.

35. Trape JF, Lefebvre-Zante E, Legros F, Ndiaye G, Bouganali H, Druilhe P, Salem G. Vector density gradients and the epidemiology of urban malaria in Dakar, Senegal. Am J Trop Med Hyg. 1992;47:181-9.

36. Midega JT, Mbogo CM, Mwnambi H, Wilson MD, Ojwang G, Mwangang $\mathrm{JM}$, et al. Estimating dispersal and survival of Anopheles gambiae and Anopheles funestus along the Kenyan coast by using mark-releaserecapture methods. J Med Entomol. 2007;44:923-9.

37. Francia ME, Striepen B. Cell division in apicomplexan parasites. Nat Rev Microbiol. 2014;12:125-36.

38. Ferreira UM, Nunes MS, Wunderlich G. Antigenic diversity and immune evasion by malaria parasites. Clin Diagn Lab Immunol. 2004;1 1:987-95.

39. Kirkman LA, Deitsch KW. Antigenic variation and the generation of diversity in malaria parasites. Curr Opin Microbiol. 2012;15:456-62.

40. Prudêncio M, Rodriguez A, Mota MM. The silent path to thousands of merozoites: the Plasmodium liver stage. Nat Rev Microbiol. 2006;4:849-56.

41. Miller LH, Ackerman HC, Xin-zhuan S, Wellems TE. Malaria biology and disease pathogenesis: insights for new treatments. Nat Med. 2013;19:156-67.

42. Eichner M, Diebner HH, Molineaux L, Collins WE, Jeffery GM, Dietz K. Genesis, sequestration and survival of Plasmodium falciparum gametocytes: parameter estimates from fitting a model to malaria therapy data. Trans R Soc Trop Med Hyg. 2001;95:497-501.

43. McGuinness D, Koram K, Bennett S, Wagner G, Nkrumah F, Riley E. Clinical case definitions for malaria: clinical malaria associated with very low parasite densities in African infants. Trans R Soc Trop Med Hyg. 1998:92:527-31.
44. Wilairatana P, Tangpukdee N, Krudsood S. Definition of hyperparasitemia in severe falciparum malaria should be updated. Asian Pac J Trop Biomed. 2013;3:586.

45. Baton LA, Ranford-Cartwright LC. Spreading the seeds of millionmurdering death: metamorphoses of malaria in the mosquito. Trends Parasitol. 2005;21:573-80.

46. Angrisano F, Tan YH, Sturm A, McFadden Gl, Baum J. Malaria parasite colonisation of the mosquito midgut-placing the Plasmodium ookinete centre stage. Int J Parasitol. 2012;42:519-27.

47. Vega-Rodríguez J, Ghosh AK, Kanzok SM, Dinglasan RR, Wang S, Bongio $\mathrm{NJ}$, et al. Multiple pathways for Plasmodium ookinete invasion of the mosquito midgut. Proc Natl Acad Sci U S A. 2014;111:492-500.

48. Hegedus D, Erlandson M, Gillott C, Toprak U. New insights into peritrophic matrix synthesis, architecture, and function. Annu Rev Entomol. 2009;54:285-302.

49. Abraham EG, Jacobs-Lorena M. Mosquito midgut barriers to malaria parasite development. Insect Biochem Mol Biol. 2004;34:667-71.

50. Han YS, Thompson J, Kafatos FC, Barillas-Mury C. Molecular interactions between Anopheles stephensi midgut cells and Plasmodium berghei: the time bomb theory of ookinete invasion of mosquitoes. EMBO J. 2000;19:6030-40.

51. Han YS, Barillas-Mury C. Implications of time bomb model of ookinete invasion of midgut cells. Insect Biochem Mol Biol. 2002;32:1311-6.

52. Hillyer JF, Barreau C, Vernick KD. Efficiency of salivary gland invasion by malaria sporozoites is controlled by rapid sporozoite destruction in the mosquito hemocoel. Int J Parasitol. 2007;37:673-81.

53. Medica DL, Sinnis P. Quantitative dynamics of Plasmodium yoelii sporozoite transmission by infected anopheline mosquitoes. Infect Immun. 2005:73:4363-9.

54. Rosenberg R, Wirtz RA, Schneider I, Burge R. An estimation of the number of malaria sporozoites ejected by a feeding mosquito. Trans R Soc Trop Med Hyg. 1990;84:209-12.

55. Amino R, Thiberge S, Martin B, Celli S, Shorte S, Frischknecht F, et al. Quantitative imaging of Plasmodium transmission from mosquito to mammal. Nat Med. 2006;12:220-4.

56. Cirimotich CM, Dong Y, Garver LS, Sim S, Dimopoulos G. Mosquito immune defenses against Plasmodium infection. Dev Comp Immunol. 2010;34:387-95.

57. Malaguarnera L, Musumeci S. The immune response to Plasmodium falciparum malaria. Lancet Infect Dis. 2002;2:472-8.

58. Hall N, Karras M, Raine JD, Carlton JM, Kooij TW, Berriman M, et al. A comprehensive survey of the Plasmodium life cycle by genomic, transcriptomic, and proteomic analyses. Science. 2005;307:82-6.

59. Florens L, Washburn MP, Raine JD, Anthony RM, Grainger M, Haynes JD, et al. A proteomic view of the Plasmodium falciparum life cycle. Nature. 2002;419:520-6.

60. Ahmed AM, Baggott SL, Maingon R, Hurd H. The costs of mounting an immune response are reflected in the reproductive fitness of the mosquito Anopheles gambiae. Oikos. 2002;97:371-7.

61. Hurd H. Manipulation of medically important insect vectors by their parasites. Annu Rev Entomol. 2003;48:141-61.

62. Sangare I, Michalakis Y, Yameogo B, Dabire R, Morlais I, Cohuet A. Studying fitness cost of Plasmodium falciparum infection in malaria vectors: validation of an appropriate negative control. Malar J. 2013;12:2.

63. Carter R, Miller LH. Evidence for environmental modulation of gametocytogenesis in Plasmodium falciparum in continuous culture. Bull World Health Organ. 1979;57:37-52.

64. Bruce MC, Alano P, Duthie S, Carter R. Commitment of the malaria parasite Plasmodium falciparum to sexual and asexual development. Parasitology. 1990;100:191-200.

65. Smith TG, Lourenço P, Carter R, Walliker D, Ranford-Cartwright LC. Commitment to sexual differentiation in the human malaria parasite, Plasmodium falciparum. Parasitology. 2000;121:127-33.

66. Mitri C, Thiery I, Bourgouin C, Paul RE. Density-dependent impact of the human malaria parasite Plasmodium falciparum gametocyte sex ratio on mosquito infection rates. Proc Biol Sci. 2009;276:3721-6.

67. Baker DA. Malaria gametocytogenesis. Mol Biochem Parasitol. 2010;172:57-65.

68. Ross A, Killeen G, Smith T. Relationships between host infectivity to mosquitoes and asexual parasite density in Plasmodium falciparum. Am J Trop Med Hyg. 2006;75:32-7. 
69. Kuehn A, Pradel G. The coming-out of malaria gametocytes. J Biomed Biotechnol. 2010;2010:976827. doi:10.1155/2010/976827.

70. Bousema T, Drakeley C. Epidemiology and infectivity of Plasmodium falciparum and Plasmodium vivax gametocytes in relation to malaria control and elimination. Clin Microbiol Rev. 2011;24:377-410.

71. Bousema T, Okell L, Shekalaghe S, Griffin JT, Omar S, Sawa P, et al. Revisiting the circulation time of Plasmodium falciparum gametocytes: molecular detection methods to estimate the duration of gametocyte carriage and the effect of gametocytocidal drugs. Malar J. 2010;9:136.

72. Smalley ME, Sinden RE. Plasmodium falciparum gametocytes: their longevity and infectivity. Parasitology. 1977;74:1-8.

73. Schneider P, Bousema JT, Gouagna LC, Otieno S, van de Vegte-Bolmer M, Omar SA, et al. Submicroscopic Plasmodium falciparum gametocyte densities frequently result in mosquito infection. Am J Trop Med Hyg. 2007;76:470-4.

74. Eckhoff P. P. falciparum infection durations and infectiousness are shaped by antigenic variation and innate and adaptive host immunity in a mathematical model. PLoS ONE. 2012;7:e44950. doi:10.1371/journal.pone.0044950

75. Da DF, Churcher TS, Yerbanga RS, Yaméogo B, Sangaré I, Ouedraogo $\mathrm{JB}$, et al. Experimental study of the relationship between Plasmodium gametocyte density and infection success in mosquitoes; implications for the evaluation of malaria transmission-reducing interventions. Exp Parasitol. 2015:149:74-83.

76. Bousema T, Okell L, Felger I, Drakeley C. Asymptomatic malaria infections: detectability, transmissibility and public health relevance. Nat Rev Microbiol. 2014;12:833-40.

77. Wampfler R, Mwingira F, Javati S, Robinson L, Betuela I, Siba P, et al. Strategies for detection of Plasmodium species gametocytes. PLoS ONE. 2013;8:e76316. doi:10.1371/journal.pone.0076316.

78. Schneider P, Schoone G, Schallig H, Verhage D, Telgt D, Eling W, et al. Quantification of Plasmodium falciparum gametocytes in differential stages of development by quantitative nucleic acid sequence-based amplification. Mol Biochem Parasitol. 2004;137:35-41.

79. Karl Stephan. Comparison of three methods for detection of gametocytes in Melanesian children treated for uncomplicated malaria. Malar J. 2014;13:319.

80. WPRO. Determining cost effectiveness of malaria rapid diagnostic tests in rural areas with high prevalence-Manila. World Health Organization Western Pacific Region. http://www.wpro.who.int/malaria/NR/ rdonlyres/OA45DF24-4245-4BF3-96E7-5F1150AF333B/0/DeterminingCostEffectivenessofRDTsinruralareaswithhighprevalence.pdf of subordinate document. Accessed 3 Feb 2016.

81. Hansen KS, Grieve E, Mikhail A, Mayan I, Mohammed N, Anwar M, et al. Cost-effectiveness of malaria diagnosis using rapid diagnostic tests compared to microscopy or clinical symptoms alone in Afghanistan. Malar J. 2015;14:217

82. Ansah EK, Epokor M, Whitty CJ, Yeung S, Hansen KS. Cost-effectiveness analysis of introducing RDTs for malaria diagnosis as compared to microscopy and presumptive diagnosis in central and peripheral public health facilities in Ghana. Am J Trop Med Hyg. 2013;89:724-36.

83. Cook J, Aydin-Schmidt B, González IJ, Bell D, Edlund E, Nassor MH, et al Loop-mediated isothermal amplification (LAMP) for point-of-care detection of asymptomatic low-density malaria parasite carriers in Zanzibar. Malar J. 2015;14:43.

84. Githeko AK, Brandling-Bennett AD, Beier M, Atieli F, Owaga M, Collins $\mathrm{FH}$. The reservoir of Plasmodium falciparum malaria in a holoendemic area of western Kenya. Trans R Soc Trop Med Hyg. 1992;86:355-8.

85. Bonnet S, Gouagna LC, Paul RE, Safeukui I, Meunier JY, Boudin C. Estimation of malaria transmission from humans to mosquitoes in two neighbouring villages in south Cameroon: evaluation and comparison of several indices. Trans R Soc Trop Med Hyg. 2003;97:53-9.

86. Churcher TS, Bousema T, Walker M, Drakeley C, Schneider P, Ouédraogo $A L$, et al. Predicting mosquito infection from Plasmodium falciparum gametocyte density and estimating the reservoir of infection. Elife. 2013;2:e00626. doi:10.7554/eLife.00626.

87. Drakeley CJ, Bousema JT, Akim NI, Teelen K, Roeffen W, Lensen AH, et al. Transmission-reducing immunity is inversely related to age in Plasmodium falciparum gametocyte carriers. Parasite Immunol. 2006:28:185-90.
88. Haji H, Smith T, Charlwood JD, Meuwissen JH. Absence of relationships between selected human factors and natural infectivity of Plasmodium falciparum to mosquitoes in an area of high transmission. Parasitology. 1996;113:425-31.

89. Bousema T, Churcher TS, Morlais I, Dinglasan RR. Can field-based mosquito feeding assays be used for evaluating transmission-blocking interventions? Trends Parasitol. 2013:29:53-9.

90. Pukrittayakamee S, Chotivanich K, Chantra A, Clemens R, Looareesuwan $\mathrm{S}$, White NJ. Activities of artesunate and primaquine against asexualand sexual-stage parasites in falciparum malaria. Antimicrob Agents Chemother. 2004;48:1329-34.

91. Song J, Socheat D, Tan B, Dara P, Deng C, Sokunthea S, et al. Rapid and effective malaria control in Cambodia through mass administration of artemisinin-piperaquine. Malaria J. 2010;9:57.

92. Graves PM, Gelband H, Garner P. Primaquine or other 8-aminoquinoline for reducing Plasmodium falciparum transmission. Cochrane Database Syst Rev. 2015;6:CD008152. doi:10.1002/14651858.CD008152.pub4.

93. Maude RJ, Socheat D, Nguon C, Saroth P, Dara P, Li G, et al. Optimising strategies for Plasmodium falciparum malaria elimination in Cambodia: primaquine, mass drug administration and artemisinin resistance. PLoS ONE. 2012;7:e37166. doi:10.1371/journal.pone.0037166.

94. Baird JK, Surjadjaja C. Consideration of ethics in primaquine therapy against malaria transmission. Trends Parasitol. 2011;27:11-6.

95. Eziefula AC, Bousema T, Yeung S, Kamya M, Owaraganise A, Gabagaya $G$, et al. Single dose primaquine for clearance of Plasmodium falciparum gametocytes in children with uncomplicated malaria in Uganda: a randomised, controlled, double-blind, dose-ranging trial. Lancet Infect Dis. 2014;14:130-9.

96. WHO. Guidelines for the treatment of malaria. 3rd ed. Geneva: WHO Library Cataloguing-in-Publication Data; 2015.

97. Pukrittayakamee S, Imwong M, Singhasivanon P, Stepniewska K, Day NJ, White NJ. Effects of different antimalarial drugs on gametocyte carriage in P. vivax malaria. Am J Trop Med Hyg. 2008;79:378-84.

98. Nacher M, Silachamroon U, Singhasivanon P, Wilairatana P, Phumratanaprapin W, Fontanet A, et al. Comparison of artesunate and chloroquine activities against Plasmodium vivax gametocytes. Antimicrob Agents Chemother. 2004:48:2751-2

99. Zeeman AM, der Wel AV, Kocken CH. Ex vivo culture of Plasmodium vivax and Plasmodium cynomolgi and in vitro culture of Plasmodium knowlesi blood stages. Methods Mol Biol. 2013;923:35-49.

100. McClean CM, Alvarado HG, Neyra V, Llanos-Cuentas A, Vinetz JM. Optimized in vitro production of Plasmodium vivax ookinetes. Am J Trop Med Hyg. 2010;83:1183-6.

101. Fivelman QL, MCRobert L, Sharp S, Taylor CJ, Saeed M, Swales CA, et al. Improved synchronous production of Plasmodium falciparum gametocytes in vitro. Mol Biochem Parasitol. 2007;154:119-23.

102. Roncalés M, Vidal-Mas J, Leroy D, Herreros E. Comparison and optimization of different methods for the in vitro production of Plasmodium falciparum gametocytes. J Parasit Res. 2012;2012:927148. doi:10.1155/2012/927148

103. Ghosh AK, Dinglasan RR, Ikadai H, Jacobs-Lorena M. An improved method for the in vitro differentiation of Plasmodium falciparum gametocytes into ookinetes. Malar J. 2010;9:194.

104. Bounkeua V, Li F, Vinetz JM. In vitro generation of Plasmodium falciparum ookinetes. Am J Trop Med Hyg. 2010;83:1187-94.

105. Delves M, Plouffe D, Scheurer C, Meister S, Wittlin S, Winzeler EA, et al. The activities of current antimalarial drugs on the life cycle stages of Plasmodium: a comparative study with human and rodent parasites. PLOS Med. 2012;9:e1001169. doi:10.1371/journal.pmed.1001169.

106. Peatey CL, Leroy D, Gardiner DL, Trenholme KR. Anti-malarial drugs: how effective are they against Plasmodium falciparum gametocytes. Malar J. 2012;11:34.

107. Lelièvre J, Almela MJ, Lozano S, Miguel C, Franco V, Leroy D, et al. Activity of clinically relevant antimalarial drugs on Plasmodium falciparum mature gametocytes in na ATP bioluminescence "transmission blocking" assay. PLoS ONE. 2012;7:e35019. doi:10.1371/journal.pone.0035019.

108. Tanaka TQ, Williamson KC. A malaria gametocytocidal assay using oxidoreduction indicator, Alamar Blue. Mol Biochem Parasitol. 2011;177:160-3.

109. Duffy $S$, Avery VM. Identification of inhibitors of Plasmodium falciparum gametocyte development. Malar J. 2013;12:408. 
110. Buchholz K, Burke TA, Williamson KC, Wiegand RC, Wirth DF, Marti $M$. A high-throughput screen targeting malaria transmission stages opens new avenues for drug development. J Infect Dis. 2011;203:1445-53.

111. Peatey CL, Spicer TP, Hodder PS, Trenholme KR, Gardiner DL. A high-throughput assay for the identification of drugs against latestage Plasmodium falciparum gametocytes. Mol Biochem Parasitol. 2011;180:127-31.

112. Miguel-Blanco C, Lelièvre J, Delves MJ, Bardera Al, Presa JL, LópezBarragán MJ, et al. Imaging-based high-throughput screening assay to identify new molecules with transmission-blocking potential against Plasmodium falciparum female gamete formation. Antimicrob Agents Chemother. 2015;59:3298-305.

113. Gamo FJ, Sanz LM, Vidal J, de Cozar C, Alvarez E, Lavandera JL, et al. Thousands of chemical starting points for antimalarial lead identification. Nature. 2010;465:305-10.

114. Rieckmann $\mathrm{KH}, \mathrm{McNamara} J \mathrm{~V}$, Frischer H, Stockert TA, Carson PE, Powell RD. Gametocytocidal and sporontocidal effects of primaquine and of sulfadiazine with pyrimethamine in a chloroquine-resistant strain of Plasmodium falciparum. Bull World Health Organ. 1968;38:625-32.

115. Wilairatana P, Krudsood S, Tangpukdee N. Appropriate time for primaquine treatment to reduce Plasmodium falciparum transmission in hypoendemic areas. Korean J Parasitol. 2010;48:179-82.

116. Lawpoolsri S, Klein EY, Singhasivanon P, Yimsamran S, Thanyavanich N, Maneeboonyang $W$, et al. Optimally timing primaquine treatment to reduce Plasmodium falciparum transmission in low endemicity ThaiMyanmar border populations. Malar J. 2009;8:159.

117. Hastings IM. Gametocytocidal activity in antimalarial drugs speeds the spread of drug resistance. Trop Med Int Health. 2006;11:1206-17.

118. Talisuna AO, Okello PE, Erhart A, Coosemans M, D'Alessandro U. Intensity of malaria transmission and the spread of Plasmodium falciparumresistant malaria: a review of epidemiologic field evidence. Am J Trop Med Hyg. 2007;77:170-80.

119. Talisuna AO, Langi P, Bakyaita N, Egwang T, Mutabingwa TK, Watkins W, et al. Intensity of malaria transmission, antimalarial-drug use and resistance in Uganda: What is the relationship between these three factors? Trans R Soc Trop Med Hyg. 2002;96:310-7.

120. Artzy-Randrup Y, Alonso D, Pascual M. Transmission intensity and drug resistance in malaria population dynamics: implications for climate change. PLOS ONE. 2010;5:e13588. doi:10.1371/journal.pone.0013588.

121. Klein EY, Smith DL, Laxminarayan R, Levin S. Superinfection and the evolution of resistance to antimalarial drugs. Proc Biol Sci. 2012;279:3834-42.

122. Johnston GL, Gething PW, Hay SI, Smith DL, Fidoc DA. Modeling withinhost effects of drugs on Plasmodium falciparum transmission and prospects for malaria elimination. PLoS Comput Biol. 2014;10:e1003434. doi:10.1371/journal.pcbi.1003434.

123. WHO. Malaria Vaccine Funders Group. Malaria vaccine technology roadmap. 2013. http://www.who.int/immunization/topics/malaria/vaccine roadmap/TRM update nov13.pdf of subordinate document. Accessed 6 Sept 2015.

124. Willyard C. Malaria eradication: blocking transmission to mosquitoes Pharm J. 2015:294:7843-4

125. Carter R. Transmission blocking malaria vaccines. Vaccine. 2001;19:2309-14

126. Pradel G. Proteins of the malaria parasite sexual stages: expression, function and potential for transmission blocking strategies. Parasitology. 2007;134:1911-29.

127. Saxena AK, Wu Y, Garboczi DN. Plasmodium p25 and p28 surface proteins: potential transmission-blocking vaccines. Eukaryot Cell. 2007;6:1260-5.

128. Tomas AM, Margos G, Dimopoulos G, van Lin LH, de Koning-Ward TF, Sinha R, et al. P25 and P28 proteins of the malaria ookinete surface have multiple and partially redundant functions. EMBO J. 2001;20:3975-83.

129. Tsai YL, Hayward RE, Langer RC, Fidock DA, Vinetz JM. Disruption of Plasmodium falciparum chitinase markedly impairs parasite invasion of mosquito midgut. Infect Immun. 2001;69:4048-54.

130. Armistead JS, Morlais I, Mathias DK, Jardim JG, Joy J, Fridman A, et al. Antibodies to a single, conserved epitope in Anopheles APN1 inhibit universal transmission of Plasmodium falciparum and Plasmodium vivax malaria. Infect Immun. 2014:82:818-29.
131. Churcher TS, Dawes EJ, Sinden RE, Christophides GK, Koella JC, Basáñez MG. Population biology of malaria within the mosquito: densitydependent processes and potential implications for transmissionblocking interventions. Malar J. 2010;9:311.

132. Wen EP, Ellis R, Pujar NS. Vaccine development and manufacturing. New York: Wiley; 2015.

133. Wu Y, Ellis RD, Shaffer D, Fontes E, Malkin EM, Mahantyet S, et al. Phase 1 trial of malaria transmission blocking vaccine candidates pfs 25 and pvs25 formulated with montanide isa 51. PLoS ONE. 2008;3:e2636. doi:10.1371/journal.pone.0002636.

134. Epstein JE, Richie TL. The whole parasite, pre-erythrocytic stage approach to malaria vaccine development: a review. Curr Opin Infect Dis. 2013;26:420-8.

135. Seder RA, Chang LJ, Enama ME, Zephir KL, Sarwar UN, Gordon IJ, et al. Protection against malaria by intravenous immunization with a nonreplicating sporozoite vaccine. Science. 2013;341:1359-65.

136. Wu Y, Przysiecki C, Flanagan E, Bello-Irizarry SN, lonescu R, Muratova O, et al. Sustained high-titer antibody responses induced by conjugating a malarial vaccine candidate to outer-membrane protein complex. Proc Natl Acad Sci U S A. 2006;103:18243-8.

137. Cheru L, Wu Y, Diouf A, Moretz SE, Muratova OV, Song G, et al. The IC50 of anti-Pfs 25 antibody in membrane feeding assay varies among species. Vaccine. 2010;28:4423-9.

138. Kumar R, Angov E, Kumar N. Potent Malaria transmission-blocking antibody responses elicited by Plasmodium falciparum Pfs25 expressed in Escherichia coli after successful protein refolding. Infect Immun. 2014;82:1453-9.

139. Theisen M, Roeffen W, Singh SK, Andersen G, Amoah L, van de VegteBolmer $\mathrm{M}$, et al. A multi-stage malaria vaccine candidate targeting both transmission and asexual parasite life-cycle stages. Vaccine. 2014;32:2623-30.

140. Kocken CH, Jansen J, Kaan AM, Beckers PJ, Ponnudurai T, Kaslow DC, et al. Cloning and expression of the gene coding for the transmission blocking target antigen Pfs48/45 of Plasmodium falciparum. Mol Biochem Parasitol. 1993;61:59-68.

141. Kaslow DC, Bathurst IC, Lensen T, Ponnudurai T, Barr PJ, Keister DB. Saccharomyces cerevisiae recombinant Pfs 25 adsorbed to alum elicits antibodies that block transmission of Plasmodium falciparum. Infect Immun. 1994;62:5576-80.

142. Zou L, Miles AP, Wang J, Stowers AW. Expression of malaria transmission-blocking vaccine antigen Pfs 25 in Pichia pastoris for use in human clinical trials. Vaccine. 2003;21:1650-7.

143. Jones RM, Chichester JA, Mett V, Jaje J, Tottey S, Manceva S, et al. A plant-produced Pfs 25 VLP malaria vaccine candidate induces persistent transmission blocking antibodies against Plasmodium falciparum in immunized mice. PLoS ONE. 2013;8:e79538. doi:10.1371/journal. pone.0079538.

144. Gregory JA, Mayfield SP. Developing inexpensive malaria vaccines from plants and algae. Appl Microbiol Biotechnol. 2014;98:1983-90.

145. Cherif MS, Shuaibu MN, Kodama Y, Kurosaki T, Helegbe GK, Kikuchi M, et al. Nanoparticle formulation enhanced protective immunity provoked by PYGPI8p-transamidase related protein (PYTAM) DNA vaccine in Plasmodium yoelii malaria model. Vaccine. 2014;32:1998-2006

146. Ferraro B, Talbott KT, Balakrishnan A, Cisper N, Morrow MP, Hutnick NA, et al. Inducing humoral and cellular responses to multiple sporozoite and liver-stage malaria antigens using exogenous plasmid DNA. Infect Immun. 2013;81:3709-20.

147. Kongkasuriyachai D, Bartels-Andrews L, Stowers A, Collins WE, Sullivan J, Sattabongkot J, et al. Potent immunogenicity of DNA vaccines encoding Plasmodium vivax transmission-blocking vaccine candidates Pvs25 and Pvs28-evaluation of homologous and heterologous antigendelivery prime-boost strategy. Vaccine. 2004;22:3205-13.

148. Doolan DL, Hoffman SL. DNA-based vaccines against malaria: status and promise of the multi-stage malaria DNA vaccine operation. Int $J$ Parasitol. 2001;31:753-62.

149. Nikolaeva D, Draper SJ, Biswas S. Toward the development of effective transmission blocking vaccines for malaria. Expert Rev Vaccines. 2015;14:653-80.

150. Wells TN, Burrows JN, Baird JK. Targeting the hypnozoite reservoir of Plasmodium vivax: the hidden obstacle to malaria elimination. Trends Parasitol. 2010;26:145-51. 
151. Clinical trials - U.S. National Institutes of Health. Testing Pfs25-EPA/Alhydrogel as a potential malaria transmission blocking vaccine. https:// clinicaltrials.gov/ct2/show/NCT01867463. Accessed 19 Sept 2015.

152. Clinical trials-U.S. National Institutes of Health. Safety and immunogenicity of plant-derived Pfs 25 VLP-FhCMB malaria transmission blocking vaccine in healthy adults https://clinicaltrials.gov/ct2/show/ NCT02013687. Accessed 19 Sept 2015.

153. WHO. Global malaria vaccine pipeline. World Health Oganization, Geneva. http://www.who.int/vaccine_research/links/Rainbow/en/ index.html. Accessed 1 Feb 2016.

154. Kubler-Kielb J, Majadly F, Biesova Z, Mocca CP, Guo C, Nussenzweig R, et al. A bicomponent Plasmodium falciparum investigational vaccine composed of protein-peptide conjugates. Proc Natl Acad Sci U S A. 2010;107:1172-7.

155. Theisen M, Roeffen W, Singh SK, Andersen G, Amoah L, van de VegteBolmer $\mathrm{M}$, et al. A multi-stage malaria vaccine candidate targeting both transmission and asexual parasite life-cycle stages. Vaccine 2014;32:2623-30.

156. Smith TA, Chitnis N, Briët OJ, Tanner M. Uses of mosquito-stage transmission-blocking vaccines against Plasmodium falciparum. Trends Parasitol. 2011;27:190-6.

157. Nunes JK, Woods C, Carter T, Raphael T, Morin MJ, Diallo D, et al. Development of a transmission-blocking malaria vaccine: progress, challenges, and the path forward. Vaccine. 2014:32:5531-9.

158. Luísa RC, Hendrickx K. Winged promises: exploring the discourse on transgenic mosquitoes in Brazil. Technol Soc. 2013;35:118-28.

159. Wang S, Jacobs-Lorena M. Genetic approaches to interfere with malaria transmission by vector mosquitoes. Trends Biotechnol. 2013;31:185-93.

160. Powell JR, Tabachnick WJ. Genetic shifting: a novel approach for controlling vector-borne diseases. Trends Parasitol. 2014;30:282-8.

161. Alphey L. Genetic control of mosquitoes. Annu Rev Entomol. 2014;59:205-14.

162. Zieler H, Keister DB, Dvorak JA, Ribeiro JM. A snake venom phospholipase A(2) blocks malaria parasite development in the mosquito midgut by inhibiting ookinete association with the midgut surface. J Exp Biol. 2001;204:4157-67.

163. Ito J, Ghosh A, Moreira LA, Wimmer EA, Jacobs-Lorena M. Transgenic anopheline mosquitoes impaired in transmission of a malaria parasite. Nature. 2002;417:452-5.

164. Knols BG, Bossin HC, Mukabana WR, Robinson AS. Transgenic mosquitoes and the fight against malaria: managing technology push in a turbulent GMO world. Am J Trop Med Hyg. 2007;77:232-42.

165. Boëte C, Agusto FB, Reeves RG. Impact of mating behaviour on the success of malaria control through a single inundative release of transgenic mosquitoes. J Theor Biol. 2014;347:33-43.

166. Windbichler N, Menichelli M, Papathanos PA, Thyme SB, Li H, Ulge UY, et al. A synthetic homing endonuclease-based gene drive system in the human malaria mosquito. Nature. 2011;473:212-5.

167. Gantza VM, Jasinskiene N, Tatarenkova O, Fazekas A, Macias VM, Bier E, et al. Highly efficient Cas9-mediated gene drive for population modification of the malaria vector mosquito Anopheles stephensi. Proc Natl Acad Sci U S A. 2015;112:6736-43. doi:10.1073/pnas.1521077112.

168. Kistler KE, Vosshall LB, Matthews BJ. Genome engineering with CRISPRCas9 in the mosquito Aedes aegypti. Cell Rep. 2015;11:51-60.

169. Hammond A, Galizi R, Kyrou K, Simoni A, Siniscalchi C, Katsanos D, et al. A CRISPR-Cas9 gene drive system targeting female reproduction in the malaria mosquito vector Anopheles gambiae. Nat Biotechnol. 2016;34:78-83.

170. Durvasula RV, Gumbs A, Panackal A, Kruglov O, Aksoy S, Merrifield RB, et al. Prevention of insect-borne disease: an approach using transgenic symbiotic bacteria. Proc Natl Acad Sci U S A. 1997;94:3274-8.

171. Riehle MA, Moreira CK, Lampe D, Lauzon C, Jacobs-Lorena M. Using bacteria to express and display anti-Plasmodium molecules in the mosquito midgut. Int J Parasitol. 2007;37:595-603.
172. Wang S, Ghosh AK, Bongio N, Stebbings KA, Lampe DJ, Jacobs-Lorena $M$. Fighting malaria with engineered symbiotic bacteria from vector mosquitoes. Proc Natl Acad Sci U S A. 2012;109:12734-9.

173. Ren X, Hoiczyk E, Rasgon JL. Viral paratransgenesis in the malaria vector Anopheles gambiae. PLoS Pathog. 2008;4:e1000135. doi:10.1371/journal. ppat.1000135.

174. Straif SC, Mbogo CN, Toure AM, Walker ED, Kaufman M, Toure YT, et al. Midgut bacteria in Anopheles gambiae and An. funestus (Diptera: Culicidae) from Kenya and Mali. J Med Entomol. 1998;35:222-6.

175. Yoshida S, loka D, Matsuoka H, Endo H, Ishii A. Bacteria expressing single-chain immunotoxin inhibit malaria parasite development in mosquitoes. Mol Biochem Parasitol. 2001;113:89-96.

176. Walker T, Moreira LA. Can Wolbachia be used to control malaria? Mem Inst Oswaldo Cruz. 2011;106:212-7.

177. Fang W, Vega-Rodríguez J, Ghosh AK, Jacobs-Lorena M, Kang A, St Leger RJ. Development of transgenic fungi that kill human malaria parasites in mosquitoes. Science. 2011;331:1074-7.

178. Konrad BP, Lindstrom M, Gumpinger A, Zhu J, Coombs D. Assessing the optimal virulence of malaria-targeting mosquito pathogens: a mathematical study of engineered Metarhizium anisopliae. Malar J. 2014;13:11.

179. Delrieu I, Leboulleux D, Ivinson K, Gessner BD, Malaria Transmission Blocking Vaccine Technical Consultation Group. Design of a Phase III cluster randomized trial to assess the efficacy and safety of a malaria transmission blocking vaccine. Vaccine. 2015;33:1518-26.

180. MalERA Consultative Group on Modeling. A research agenda for malaria eradication: modeling. PLoS Med. 2011;8:e1000403. doi:10.1371/journal. pmed. 1000403 .

181. White LJ, Maude RJ, Pongtavornpinyo W, Saralamba S, Aguas R, Van Effelterre $T$, et al. The role of simple mathematical models in malaria elimination strategy design. Malar J. 2009;8:212.

182. Griffin JT, Hollingsworth TD, Okell LC, Churcher TS, White M, Hinsley W, et al. Reducing Plasmodium falciparum malaria transmission in africa: a model-based evaluation of intervention strategies. PLoS Med. 2010;7:e1000324. doi:10.1371/journal.pmed.1000324.

183. Najera JÁ, González-Silva M, Alonso PL. Some lessons for the future from the global malaria eradication programme (1955-1969). PLoS Med. $2011 ; 8:$ :1000412. doi:10.1371/journal.pmed.1000412.

184. Cohen JM, Smith DL, Cotter C, Ward A, Yamey G, Sabot OJ, et al. Malaria resurgence: a systematic review and assessment of its causes. Malar J. 2012;11:122.

185. Artzy-Randrup Y, Andrew P, Dobsond AP, Pascua M. Synergistic and antagonistic interactions between bednets and vaccines in the control of malaria. Proc Natl Acad Sci U S A. 2015;112:3014-9.

186. Tatem AJ, Smith DL, Gething PW, Kabaria CW, Snow RW, Hay SI. Ranking of elimination feasibility between malaria-endemic countries. Lancet. 2010;376:1579-91.

187. Mills A, Lubell Y, Hanson K. Malaria eradication: the economic, financia and institutional challenge. Malar J. 2008;7:11.

188. WHO. Use of MenAfriVac ${ }^{\mathrm{TM}}$ (meningitis A vaccine) in a controlled temperature chain(CTC) during campaigns. 2013. www.who.int/immunization/documents/WHO_IVB_13.04_5_6/en/ Accessed 20 Sept 2015.

189. RTS,S Clinical Trials Partnership. Efficacy and safety of RTS, S/AS01 malaria vaccine with or without a booster dose in infants and children in Africa: final results of a phase 3, individually randomised, controlled trial. Lancet. 2015;2015(386):31-45.

190. Penny MA, Verity R, Bever CA, Sauboin C, Galactionova K, Flasche S, et al. Public health impact and cost-effectiveness of the RTS, S/AS01 malaria vaccine: a systematic comparison of predictions from four mathematical models. Lancet. 2016;387:367-75.

191. Reeves RG, Denton JA, Santucci F, Bryk J, Reed FA. Scientific standards and the regulation of genetically modified insects. PLoS Negl Trop Dis. 2012;6:e1502. doi:10.1371/journal.pntd.0001502. 